\title{
Evaluating antimicrobial resistance patterns of the etiological agents of urinary tract infections
}

Doaa Hisham ${ }^{1}$, Osama Y Safdar ${ }^{2}$, Mohammed Shalaby², Mohammed Sabbahi ${ }^{1}$, Mowadah Ashgar ${ }^{1}$, Rahaf Shafi ${ }^{1}$, Dina Binmahfoodh ${ }^{1}$, and Darwish Khizindar ${ }^{1}$

1. Faculty of Medicine, King Abdulaziz University, Saudi Arabia

2. Pediatric Nephrology Center of Excllence, Faculty of Medicine, King Abdulaziz University, Saudi Arabia

\section{RESEARCH}

Please cite this paper as: Hisham D, Safdar OY, Shalaby M, Sabbahi M, Ashgar M, Shafi R, Binmahfoodh D, Khizindar D. Evaluating antimicrobial resistance patterns of the etiological agents of urinary tract infections. AMJ 2018;11(2):96-106.

https://doi.org/10.21767/AMJ.2018.3310

Corresponding Author:

Dr. Osama Y Safdar

Assistant Professor of Pediatrics

Pediatric Nephrology Center of Excllence,

Faculty of Medicine, King Abdulaziz University

PO BOX 14071, postal code 21414

Alsulimania, Jeddah, Saudi Arabia

Email: Safderosama@hotmail.com

\section{ABSTRACT}

\section{Background}

Antimicrobial resistance has been presented as a highly prevailing condition.

\section{Aims}

To evaluate antimicrobial resistance patterns of the etiological agents of urinary tract infection among children in Saudi Arabia.

\section{Methods}

A retrospective population-based epidemiological study has been conducted at King Abdulaziz University Hospital, Saudi Arabia, from the year 2016-2017. It has recruited individuals with clinical diagnosis of urinary tract infection, particularly.
Results

The study has recruited 63 participants on the basis of inclusion criteria. Among these, majority were males with the prevalence of 54 per cent $(n=34)$; while females were 46 per cent $(n=29)$. Most of the participants were under the age of two years with the prevalence of 50.8 per cent $(n=32)$, then children of 2 years with 34.9 per cent $(n=22)$; and older than two years with 14.3 per cent $(n=9)$. Resistance to ampicillin was observed in 12.7 per cent cases; resistance to ciprofloxacin was observed in 1.6 per cent; resistance to cotrimoxazole was witnessed in 3.2 per cent; and multidrug resistance was observed in 30.2 per cent of the patients.

\section{Conclusion}

Clinical management of urinary tract infections is a challenge that mainly presents antimicrobial resistance as the point of concern.

\section{Key Words}

Drug, ampicillin, ciprofloxacin, urinary tract infections

\section{What this study adds:}

\section{What is known about this subject?}

Antimicrobial resistance patterns have been observed to occur significantly in parallel to the condition of urinary tract infections.

\section{What new information is offered in this study?}

Resistance to ampicillin was observed among 12.7 per cent cases; resistance to ciprofloxacin in 1.6 per cent cases; resistance to cotrimoxazole in 3.2 per cent cases; and multidrug resistance in $\mathbf{3 0 . 2}$ per cent cases.

3. What are the implications for research, policy, or practice?

Clinical management of urinary tract infections is vital to reduce the risk of renal mortality and morbidity. 


\section{Background}

Antimicrobial resistance is emerging as a prevalent condition, significantly among the patients of urinary tract infections (UTIS). It has been found to be prevalent regardless of the age group of the patients. ${ }^{1}$ Organisms causing the UTIs enter the urinary tract system from environment through urethra and bladder and travel upward via urinary orifice. Eventually, these infections occur more commonly among females than males, due to the differences in anatomical features. ${ }^{2}$ Pathogenesis of urine infections tend to vary from one patient to another. The variation usually depends on the attributes of age, gender, sexual activities, bathroom habits, catheter application, clinical setting, and exposure of the patient to antimicrobial agents in the past. ${ }^{1}$

Resistance to antimicrobial agents in the cases of urine infections has been increasing significantly. The variation has been noted to differ according to the regional and geographical settings of the patients. ${ }^{2,3}$ Thus, it has been deemed necessary to collect and present the significant information concerning the course of action as offered by the etiological factors of UTIs, with which they express resistance to the treatment modalities. ${ }^{4}$

Urine infection has been recognized as the most prevalent form of infection that appears to range from asymptomatic occurrence to severity of indications that may even cause sepsis in the organs. Among all the hospital acquired infections, UTIs are the second most common cause of hospital related morbidity and deaths. ${ }^{5}$ It has been observed that majority of the urine infections are infested by the influence of gram negative bacteria. The most common pathological agent causing UTIs is identified as Escherichia coli. Other types of gram negative bacteria may also include Klebsiella species, Pseudomonas aeruginosa, Acinetobacter, Proteus mirabilis, and Serratia. ${ }^{5,6}$

These urinary pathogens are kept under serious consideration to identify the antimicrobial resistance towards these agents. Limiting response to the condition due to the expression of resistance by these etiological factors is considered as a major contributing element to the healthcare expenses. According to Grandy, Fox \& Hardy (2013), around 150 million cases of urine infections will be reported in a year, from around the world. It has been recorded that about 20 per cent of males may experience the symptoms of urinary tract infections; while, half of the females will experience the symptoms of urinary tract infections once in life. ${ }^{7}$ It is important to realize the associated situations of urinary disorders as the infestation evidently tends to recur in the patients. The identification is crucial as the chronic influence can cause pyelonephritis and may also lead to renal failure. ${ }^{7}$

The rising prevalence of antimicrobial resistance among the patients of urine infections have been emerging as a challenge in the urology field. The entity has suppressed the success results of treatment with the antibiotics; therefore, the degree of recurrence is also increasing in the clinical setting. Modification in the expression of uropathogens is responsible for building resistance towards a specific drug. Recurrence, along with resistance, has presented serious setbacks in managing and treating the UTIs. It is presumed that if resistance is reduced among the urine infection pathogens, recurrence can also be managed. It is necessary to attain the knowledge of etiological factors, associated with the disease and their association with the drug expression to remove the clinical setbacks. ${ }^{8}$

The purpose of the study is to acquire knowledge regarding the antimicrobial resistance patterns of the etiological agents of urinary tract infections amongst the children in Saudi Arabia. The study has presented the knowledge that can assist to develop better treatment alternatives for the UTIs. It is a necessary aspect as the persistence of urine infections can lead to chronic conditions like renal scarring, hypertension, and end stage renal failure. ${ }^{3}$

\section{Method}

\section{Study design}

A retrospective population-based epidemiological study has been designed for the fulfilment of set objectives. The study has been conducted for the period of one year. The children with the clinical diagnosis of urinary tract infection, presenting at the clinical setting of King Abdulaziz University Hospital, Saudi Arabia, have been assessed from the year 2016-2017.

\section{Inclusion and exclusion criteria}

The data of only those patients was taken, who have been provided with the clinical diagnosis of urinary tract infections by their doctors. It was also noted that further referred for the assessment and treatment has been provided. All the participants have been selected from the patient database of the selected clinical settings. Patients with any comorbidity and at stage of chronic condition have been excluded from the study.

\section{Data collection}

Data for all the patients has been collected for the demographic and clinical parameters. Demographic factors 
included age and gender. Clinical paradigms have included the type of drug resistance, congenital anomalies, and frequency of urinary tract infections, frequency of episodes, atypical features of urine infections, hydronephrosis, and the degree of reflux.

\section{Identification and estimation of uropathogens}

A surface streak procedure was performed to isolate uropathogens through calibrated loops for the semiquantitative method. The samples were incubated aerobically for 24 hours at 37 degrees centigrade. The negative samples were further incubated for 48 hours. In a sample, if a single organism was cultures at the concentration of $\geq 105 \mathrm{cfu} / \mathrm{ml}$, then it was termed positive for UTI.

\section{Ethical consideration}

Ethical approval for the study was obtained from the Ethical Review Board of King Abdulaziz University Hospital, Saudi Arabia, before the commencement of the protocol.

\section{Statistical analysis}

All the collected information has been coded and fed into the data sheets. Correlation analysis was performed on the recorded parameters for determining the association of urine infection and its etiologic factors with drug resistance. Data has been analysed through Statistical Package for the Social Science (SPSS).

\section{Results}

The study has recruited 63 participants on the basis of inclusion criteria. Among these, majority were males with the prevalence of 54 per cent $(n=34)$; while females were 46 per cent $(n=29)$. The prevalence of UTI was increased among majority of the participants under the age of two years with the prevalence of 50.8 per cent $(n=32)$, then children of two years with 34.9 per cent $(n=22)$; and older than 2 years with 14.3 per cent $(n=9)$. Table 1 has displayed the physical attributes as recorded for the patients of UTI. Table 2 has presented the clinical observations for the study group. Table 3 has displayed the treatment response and resistance towards antibiotic drugs.

Table 4 has presented that patients, under the age of two years, have expressed 59.4 per cent of no-drug resistance, 25 per cent of multidrug resistance, 9.4 per cent of ampicillin resistance, 6.2 per cent cotrimoxazole, and 0 per cent ciprofloxacin resistance.

Two-year-old had 40.9 per cent no-drug resistance, 40.9 per cent multidrug resistance, 13.6 per cent ampicillin resistance, 4.5 per cent ciprofloxacin, and 0 per cent resistance to cotrimoxazole. On the other hand, children above two years had 55.6 per cent of no-drug resistance, 22.2 per cent multidrug resistance, 22.2 per cent ampicillin resistance, 0 per cent ciprofloxacin resistance, and cotrimoxazole resistance, respectively. With the significance of $p=0.545$, no relationship between age and type of drug resistance has been identified.

Among the study group, 51.7 per cent females had no resistance to drugs, 41.4 per cent had multidrug resistance, 6.9 per cent ampicillin resistance, 0 per cent ciprofloxacin, and 0 per cent cotrimoxazole resistance (Table 5). While, among males, 52.9 per cent had no-drug resistance, 20.6 per cent had multidrug resistance, 17.6 per cent ampicillin resistance, 2.9 per cent ciprofloxacin and 5.9 per cent cotrimoxazole resistance. There was no relationship between gender and type of drug resistance $(p=0.183)$.

As displayed in Table 6, patients with congenital anomalies have presented that 75.0 per cent had no-drug resistance, 16.7 per cent had multidrug resistance, 8.3 per cent had ampicillin resistance, 0 per cent ciprofloxacin, and 0 per cent cotrimoxazole resistance. Among those without any congenital abnormalities, 47.1 per cent had no-drug resistance, 33.3 per cent had multidrug resistance, 13.7 per cent had ampicillin resistance, 2.0 per cent ciprofloxacin resistance, and 3.9 per cent cotrimoxazole resistance. There was no association between gender and type of drug resistance $(p=0.183)$. Moreover, there was no association between congenital anomalies and type of drug resistance $(p=0.514)$.

Among the patients with first episode of UTI, 61.4 per cent had no-drug resistance, 22.7 per cent had multidrug resistance, and 15.9 per cent had ampicillin resistance, 0 per cent ciprofloxacin, and 0 per cent cotrimoxazole resistance (Table 7). Among those with recurrent episodes, 27.8 per cent had no drug resistance, 50.0 per cent had multidrug resistance, 5.6 per cent had ampicillin resistance, 5.6 per cent to ciprofloxacin, and 11.1 per cent cotrimoxazole resistance. There was no relationship between frequency of UTI and type of drug resistance $(p=0.53)$.

Among the patients with typical features of UTI, 55.0 per cent had no drug resistance, 40.0 per cent had multidrug resistance, and 5.0 per cent had ampicillin, 0 per cent ciprofloxacin, and 0 per cent cotrimoxazole resistance (Table 8). Among patients with atypical features of UTI, 51.2 per cent had no drug resistance; while, 25.6 per cent had multidrug, 16.3 per cent ampicillin, 2.3 per cent 
ciprofloxacin, and 4.7 per cent cotrimoxazole resistance. There was no relationship between atypical features of UTI and type of drug resistance $(p=0.442)$.

Among the patients with hydronephrosis, diagnosed by ultrasound scanning, 46.7 per cent had no-drug resistance, 40.0 per cent had multidrug resistance, 6.7 per cent had ampicillin resistance, 6.7 per cent ciprofloxacin resistance, and 0 per cent resistant to cotrimoxazole (Table 9). Among patients with no indication of hydronephrosis, 53.8 per cent had no-drug resistance, 25.69 per cent had multidrug resistance, and 15.4 per cent had ampicillin resistance, 0 per cent ciprofloxacin resistance, and 5.1 per cent cotrimoxazole resistance. Among patients, who did not undergo ultrasound scanning; 55.6 per cent had no drug resistance, 33.3 per cent had multidrug resistance, 11.1 per cent had ampicillin, 0 per cent ciprofloxacin resistance, and 0 per cent cotrimoxazole resistance. There was no relationship between hydronephrosis of UTI and type of drug resistance $(p=0.647)$.

Table 10 has presented that patients with grade 1 vesicoureteral reflux expressed 100 per cent resistance to multidrug treatment. Patients with Grade 3 vesicoureteral reflux had 0 per cent drug resistance; while, those with Grade 4 vesicoureteral reflux had no-drug resistance. Among patients with no vesicoureteral reflux, 52.5 per cent had no drug resistance, 28.8 per cent had multidrug resistance, 13.6 per cent had ampicillin, 1.7 per cent had ciprofloxacin, and 3.4 per cent had cotrimoxazole resistance. There was no relationship between degree of reflux and type of drug resistance $(p=0.887)$.

\section{Discussion}

The study has extensively studied the clinical attributes of patients, who have been suffering from urine infections. Outcomes have provided data to perform a comparative analysis on the incidence of antimicrobial resistance as expressed for the pathogens, causing urine infections. It has been asserted by several studies that the incidence of urinary tract infections tends to be higher among females as compared to males. ${ }^{9-11}$ The results of present study have presented the same prevalence. Females contract the urinary infections more conveniently due to the shorter distance of urethra to anus. ${ }^{12}$ On the other hand, the prostatic fluid consists of substances that express antimicrobial activities, which decreases the susceptibility among males to contract the infections. ${ }^{13}$

Intervention with antimicrobial drugs has been rapidly increasing around the world to compete with the treatment of urine infections. The widespread usage has led to an abuse of drug globally. The modality has exhausted the human resistance model in such a way that the infectious pathogens have evolved to express resistance towards the administered drugs. It has been observed with time that drug resistance has associations with the patterns of microorganisms. ${ }^{14}$ As per the estimations provided by ARESC or Antimicrobial Resistance Epidemiological Survey on Cystitis, 74.6 per cent of the study group have expressed positive results for urine culture. Most of the outcomes had Escherichia coli (E. coli). ${ }^{15}$ Centers for Disease Control and Prevention has identified the categorization of bacterial isolates in the form of urgent and serious threats. These isolates have been known to impose serious clinical risk and economic burden on the health care system and pateints. ${ }^{16}$ Multidrug resistance has been reported with high prevalence in the study conducted by Chang et al. Multidrug therapy is mainly induced in the cases of infections that have been known to be significant yet expensive in treating the diseases. Despite of extensive researches, particular driving processes for the bacterial agents have not been recorded well. Lack of knowledge leads to the administration of either multiple intervention of drugs or abused administration. ${ }^{17}$ Ciprofloxacin are synthetic antimicrobials that have been facing an emerging resistance from the bacteria causing urine infections. Unlike multidrug resistance, the process of resistance in ciprofloxacin has been studied. It has been comprehended that it occurs with the genetic mutations and acquisition of genes conferring to gene resistance. $^{18}$

Recurrence of UTIs have been further determined as a strong factor, contributing to the repeatedly occurring infections and sensitivity to antimicrobial treatment. These are further influenced by the intracellular reservoirs of bacterial isolates, lining the mucosal wall of bladder. Consideration of such pathological factors has been presumed to have a strong role in the clinical aspects of the infections and resistance. A study tried for creating surveillance data on antibiotic resistance, type of infection, and consumption of antibiotic among the patients. ${ }^{19}$ The results showed increased resistance rates for majority of the uropathogens against the antibiotics, along with the multidrug resistance. Another study conducted by Wagenlehner et al. $^{20}$ evaluated urology practice for controlling hospital infection and antibiotic consumption practice. The study helped in delivering data for appropriate antibiotic therapy among the hospitalized patients suffering from UTIs. 


\section{Conclusion}

UTIs are identified as a burden to the healthcare facility, regardless of the fact that it is a treatable condition. Clinical management of urine infections has been presented as a major challenge due to the rising rate of antimicrobial resistance. Findings have presented that urinary tract infections have been expressing high rate of antimicrobial resistance. It is needed that researchers now look into modalities that can enhance the treatment actions of antimicrobial agents.

\section{References}

1. Biadglegne F, Abera $B$. Antimicrobial resistance of bacterial isolates from urinary tract infections at Felge Hiwot Referral Hospital, Ethiopia. Ethiop J Health Dev. 2016;23(3).

2. Foxman B. Urinary tract infection syndromes: occurrence, recurrence, bacteriology, risk factors, and disease burden. Infect Dis Clin North Am. 2014;28(1):13. doi: https://doi.org/10.1016/j.idc.2013.09.003

3. Gajjar R, Amaral S. The Contribution of Urinary Tract Infection to Chronic Kidney Disease in Children: An Entity in Evolution. J Pediatr Infect Dis. 2016;11(03):728.

4. Linhares I, Raposo T, Rodrigues A, et al. Frequency and antimicrobial resistance patterns of bacteria implicated in community urinary tract infections: a ten-year surveillance study (2000-2009). BMC Infectious Diseases. 2013;13(1):19. doi: 10.1186/1471-2334-13-19

5. Amber $M$, Shoaib $M$, Rehman $A$, et al. Comparative study of Causative agents of UTI among Indoor, outdoor, Children and Adult Patients of Pakistani Population. Bull Env Pharmacol Life Sci. 2016;5:34-41.

6. Osthoff M, McGuinness SL, Wagen AZ, et al. Urinary tract infections due to extended-spectrum betalactamase-producing Gram-negative bacteria: identification of risk factors and outcome predictors in an Australian tertiary referral hospital. International J Infect Dis. 2015;34:79-83. doi: https://doi.org/10.1016/j.ijid.2015.03.006

7. Grandy S, Fox KM, Hardy E. Prevalence and recurrence of urinary tract and genital infections among adults with and without type 2 diabetes mellitus in the general population: a longitudinal cohort study. J Diabetes Res Clin Metab. 2013;2(1):5. doi: http://dx.doi.org/10.7243/2050-0866-2-5

8. Barber $A E$, Norton JP, Spivak $A M$, et al. Urinary tract infections: current and emerging management strategies. Clin Infect Dis. 2013;57(5):719-24. doi: https://doi.org/10.1093/cid/cit284

9. Rajalakshmi V, Amsaveni V. Antibiotic susceptibility of bacterial pathogens isolated from diabetic patients. Int J Microbiol Res. 2012;3(1):30-2.

10. Oladeinde $\mathrm{BH}$, Omoregie $\mathrm{R}$, Olley $\mathrm{M}$, et al. Urinary tract infection in a rural community of Nigeria. N Am J Med Sci. 2011;3(2):75. doi:10.4297/najms.2011.375

11. Sood S, Gupta R. Antibiotic resistance pattern of community acquired uropathogens at a tertiary care hospital in Jaipur, Rajasthan. Indian J Community Med. 2012;37(1):39. doi: 10.4103/0970-0218.94023

12. Tula MY, lyoha, $O$. Distribution and antibiotic susceptibility pattern of bacterial pathogens causing urinary tract infection in Mubi general hospital, YolaNigeria. Br J Med Med Res. 2014;4(19):3591-3602.

13. Wagenlehner FM, Pilatz $A$, Waliszewski $P$, et al. Reducing infection rates after prostate biopsy. Nat Rev Urol. 2014;11(2):80-6. doi:10.1038/nrurol.2013.322

14. Ren W, Fang Y, Chen W, et al. Patterns of etiology and antibiotic resistance of bacteria causing urinary tract infections in the Anhui Provincial Hospital. Int J Clin Exp Med. 2016;9(2):4515-20.

15. Schito GC, Naber KG, Botto $H$, et al. The ARESC study: an international survey on the antimicrobial resistance of pathogens involved in uncomplicated urinary tract infections. Int J Antimicrob Agents. 2009;34(5):407-13. doi: https://doi.org/10.1016/j.ijantimicag.2009.04.012

16. Ventola CL. The antibiotic resistance crisis: part 1: causes and threats. P T. 2015;40(4):277.

17. Chang $\mathrm{HH}$, Cohen $\mathrm{T}, \mathrm{Grad} \mathrm{YH}$, et al. Origin and proliferation of multiple-drug resistance in bacterial pathogens. Microbiol Mol Biol Rev. 2015;79(1):101-16. doi: 10.1128/MMBR.00039-14

18. Hooper DC, Jacoby GA. Mechanisms of drug resistance: quinolone resistance. Ann N Y Acad Sci. 2015;1354(1):12-31. doi: 10.1111/nyas.12830

19. Wagenlehner F, Tandogdu Z, Bartoletti R, et al. The Global Prevalence of Infections in Urology Study: A LongTerm, Worldwide Surveillance Study on Urological Infections. Pathogens. 2016;5:10. doi: 10.3390/pathogens5010010

20. Wagenlehner F, Tandogdu Z, Bartoletti R, et al. The Global Prevalence of Infections in Urology (GPUI) Study: A Worldwide Surveillance Study in Urology Patients. Eur Urol Focus. 2016:345-347.

\section{ACKNOWLEDGEMENTS}

The author is very thankful to all the associated personnel in any reference that contributed in/for the purpose of this research

\section{PEER REVIEW}

Not commissioned. Externally peer reviewed. 


\section{CONFLICTS OF INTEREST}

The authors declare that they have no competing interests.

\section{FUNDING}

None

\section{ETHICS COMMITTEE APPROVAL}

Ethical approval for the study was obtained from the Ethical Review Board of King Abdulaziz University Hospital, Saudi Arabia. 
Table 1: Physical record of the UTI patients

\begin{tabular}{|l|l|l|l|l|l|}
\hline Descriptive Statistics & N & Minimum & Maximum & Mean & Std. Deviation \\
\hline $\begin{array}{l}\text { Weight } \\
\text { (pounds) }\end{array}$ & 63 & 0.00 & 24.80 & 4.3946 & 4.46958 \\
\hline $\begin{array}{l}\text { Height } \\
\text { (inches) }\end{array}$ & 63 & 0 & 100 & 53.03 & 13.537 \\
\hline $\begin{array}{l}\text { Temperature } \\
\text { (centigrade) }\end{array}$ & 63 & 36.0 & 40.0 & 36.823 & 0.8537 \\
\hline $\begin{array}{l}\text { Serum creatinine on admission } \\
\text { (mg/dl) }\end{array}$ & 63 & 0 & 137 & 37.54 & 21.834 \\
\hline $\begin{array}{l}\text { Serum creatinine on discharge } \\
\text { (mg/dl) }\end{array}$ & 63 & 1 & 48 & 14.51 & 16.946 \\
\hline $\begin{array}{l}\text { Serum creatinine at last follow } \\
\text { up visit (mg/dl) }\end{array}$ & 63 & 1 & 97 & 15.03 & 20.424 \\
\hline
\end{tabular}

Table 2: Clinical record of the UTI patients

\begin{tabular}{|c|c|c|}
\hline $\begin{array}{l}\text { Neonatal Sepsis } \\
\text { Yes } \\
\text { No }\end{array}$ & $\begin{array}{l}\text { Frequency }(\mathrm{N}=63) \\
34 \\
29\end{array}$ & $\begin{array}{l}\text { Prevalence } \\
54.00 \% \\
46.00 \%\end{array}$ \\
\hline $\begin{array}{l}\text { Spina Bifida and Neurogenic Bladder } \\
\text { Yes } \\
\text { No }\end{array}$ & $\begin{array}{l}\text { Frequency }(\mathrm{N}=63) \\
1 \\
62\end{array}$ & $\begin{array}{l}\text { Prevalence } \\
1.60 \% \\
98.40 \%\end{array}$ \\
\hline $\begin{array}{l}\text { Vesicouretral Reflux } \\
\text { Yes } \\
\text { No }\end{array}$ & $\begin{array}{l}\text { Frequency }(N=63) \\
6 \\
57\end{array}$ & $\begin{array}{l}\text { Prevalence } \\
9.50 \% \\
90.50 \%\end{array}$ \\
\hline $\begin{array}{l}\text { Obstructive Uropathy } \\
\text { Yes } \\
\text { No }\end{array}$ & $\begin{array}{l}\text { Frequency }(\mathrm{N}=63) \\
4 \\
59\end{array}$ & $\begin{array}{l}\text { Prevalence } \\
6.30 \% \\
93.70 \%\end{array}$ \\
\hline $\begin{array}{l}\text { Other Congenital Anomalies } \\
\text { Yes } \\
\text { No }\end{array}$ & $\begin{array}{l}\text { Frequency }(\mathrm{N}=63) \\
12 \\
51\end{array}$ & $\begin{array}{l}\text { Prevalence } \\
19.00 \% \\
81.00 \%\end{array}$ \\
\hline $\begin{array}{l}\text { Blood Pressure } \\
\text { Not Recorded } \\
\text { Normal } \\
\text { Pre HTN } \\
\text { HTN }\end{array}$ & $\begin{array}{l}\text { Frequency }(\mathrm{N}=63) \\
4 \\
49 \\
4 \\
6\end{array}$ & $\begin{array}{l}\text { Prevalence } \\
6.30 \% \\
77.80 \% \\
6.30 \% \\
9.50 \%\end{array}$ \\
\hline $\begin{array}{l}\text { Temperature Grade } \\
\text { Not Recorded } \\
\text { Low Grade } 36-38 \text { C } \\
\text { High Grade } 39-40 \text { C }\end{array}$ & $\begin{array}{l}\text { Frequency }(\mathrm{N}=63) \\
2 \\
58 \\
3\end{array}$ & $\begin{array}{l}\text { Prevalence } \\
3.20 \% \\
92.10 \% \\
4.80 \%\end{array}$ \\
\hline $\begin{array}{l}\text { Frequency of UTI } \\
\text { None } \\
\text { First Episode } \\
\text { Recurrent }\end{array}$ & $\begin{array}{l}\text { Frequency }(\mathrm{N}=63) \\
1 \\
44 \\
18\end{array}$ & $\begin{array}{l}\text { Prevalence } \\
1.60 \% \\
69.80 \% \\
28.00 \% \\
\end{array}$ \\
\hline $\begin{array}{l}\text { Atypical Features } \\
\text { Present } \\
\text { None }\end{array}$ & $\begin{array}{l}\text { Frequency }(\mathrm{N}=63) \\
20 \\
43\end{array}$ & $\begin{array}{l}\text { Prevalence } \\
31.70 \% \\
68.30 \%\end{array}$ \\
\hline
\end{tabular}




\begin{tabular}{|l|l|l|} 
Poor Stream & Frequency (N=63) & Prevalence \\
Yes & 1 & $1.60 \%$ \\
\hline Degree of Reflux & 62 & $98.40 \%$ \\
None & Frequency (N=63) & Prevalence \\
Grade 1 & 59 & $93.70 \%$ \\
Grade 2 & 1 & $3.20 \%$ \\
Grade 3 & 0 & $0.00 \%$ \\
Grade 4 & 2 & $1.60 \%$ \\
\hline Hydronephrosis & 1 & $1.60 \%$ \\
Yes & Frequency (N=63) & Prevalence \\
No & 15 & $23.80 \%$ \\
\hline DTPA & 39 & $61.90 \%$ \\
Not recorded & Frequency (N=63) & Prevalence \\
Obstructive & 56 & $88.90 \%$ \\
Non obstructive & 2 & $3.20 \%$ \\
\hline Renal Failure & 5 & $2 \%$ \\
Yes & Frequency (N=63) & Prevalence \\
No & 0 & $0.00 \%$ \\
\hline
\end{tabular}

Table 3: Antibiotic treatment and resistance

\begin{tabular}{|l|l|l|}
\hline No Response to Antibiotic within $\mathbf{4 8}$ hrs. & Frequency (N=63) & Prevalence \\
Yes & 15 & $23.80 \%$ \\
No & 48 & 76.25 \\
\hline Drug Resistance & Frequency (N=63) & Prevalence \\
Resistance to penicillin & 8 & $12.70 \%$ \\
Resistance to quinolones & 1 & $1.60 \%$ \\
Resistance to sylph & 2 & $3.20 \%$ \\
Multidrug resistance & 19 & $30.20 \%$ \\
None & 33 & $52.40 \%$ \\
\hline
\end{tabular}

Table 4: Relationship between age and drug resistance

\begin{tabular}{|c|c|c|c|c|c|c|c|c|}
\hline & \multicolumn{5}{|c|}{ Type of drugs resistance } & \multirow[b]{2}{*}{ Total } \\
\hline & & & $\begin{array}{l}\text { Resistance } \\
\text { to penicillin }\end{array}$ & $\begin{array}{l}\text { Resistance to } \\
\text { quinolones }\end{array}$ & $\begin{array}{l}\text { Resistance } \\
\text { to sylph }\end{array}$ & $\begin{array}{l}\text { Multidrug } \\
\text { resistance }\end{array}$ & None & \\
\hline \multirow{3}{*}{ Age } & $\begin{array}{l}\text { Less Than } \\
\text { Two Years }\end{array}$ & $\begin{array}{l}\text { Count } \\
\% \text { within Age }\end{array}$ & $\begin{array}{c}3 \\
9.40 \% \\
\end{array}$ & $\begin{array}{c}0 \\
0.00 \% \\
\end{array}$ & $\begin{array}{c}2 \\
6.20 \% \\
\end{array}$ & $\begin{array}{c}8 \\
25.00 \% \\
\end{array}$ & $\begin{array}{c}19 \\
59.40 \% \\
\end{array}$ & $\begin{array}{c}32 \\
100.00 \% \\
\end{array}$ \\
\hline & 2 Years & $\begin{array}{l}\text { Count } \\
\% \text { within Age }\end{array}$ & $\begin{array}{c}3 \\
13.60 \% \\
\end{array}$ & $\begin{array}{c}1 \\
4.50 \% \\
\end{array}$ & $\begin{array}{c}0 \\
0.00 \% \\
\end{array}$ & $\begin{array}{c}9 \\
40.90 \% \\
\end{array}$ & $\begin{array}{c}9 \\
40.90 \% \\
\end{array}$ & $\begin{array}{c}22 \\
100.00 \% \\
\end{array}$ \\
\hline & $\begin{array}{l}\text { More Than } \\
\text { Two Years }\end{array}$ & $\begin{array}{l}\text { Count } \\
\% \text { within Age }\end{array}$ & $\begin{array}{c}2 \\
22.20 \%\end{array}$ & $\begin{array}{c}0 \\
0.00 \%\end{array}$ & $\begin{array}{c}0 \\
0.00 \%\end{array}$ & $\begin{array}{c}2 \\
22.20 \%\end{array}$ & $\begin{array}{c}5 \\
55.60 \%\end{array}$ & $\begin{array}{c}9 \\
100.00 \%\end{array}$ \\
\hline \multicolumn{2}{|r|}{ Total } & $\begin{array}{l}\text { Count } \\
\% \text { within Age }\end{array}$ & $\begin{array}{c}8 \\
12.70 \%\end{array}$ & $\begin{array}{c}1 \\
1.60 \%\end{array}$ & $\begin{array}{c}2 \\
3.20 \%\end{array}$ & $\begin{array}{c}19 \\
30.20 \%\end{array}$ & $\begin{array}{c}33 \\
52.40 \%\end{array}$ & $\begin{array}{c}63 \\
100.00 \%\end{array}$ \\
\hline
\end{tabular}


Table 5: Relationship between gender and drug resistance

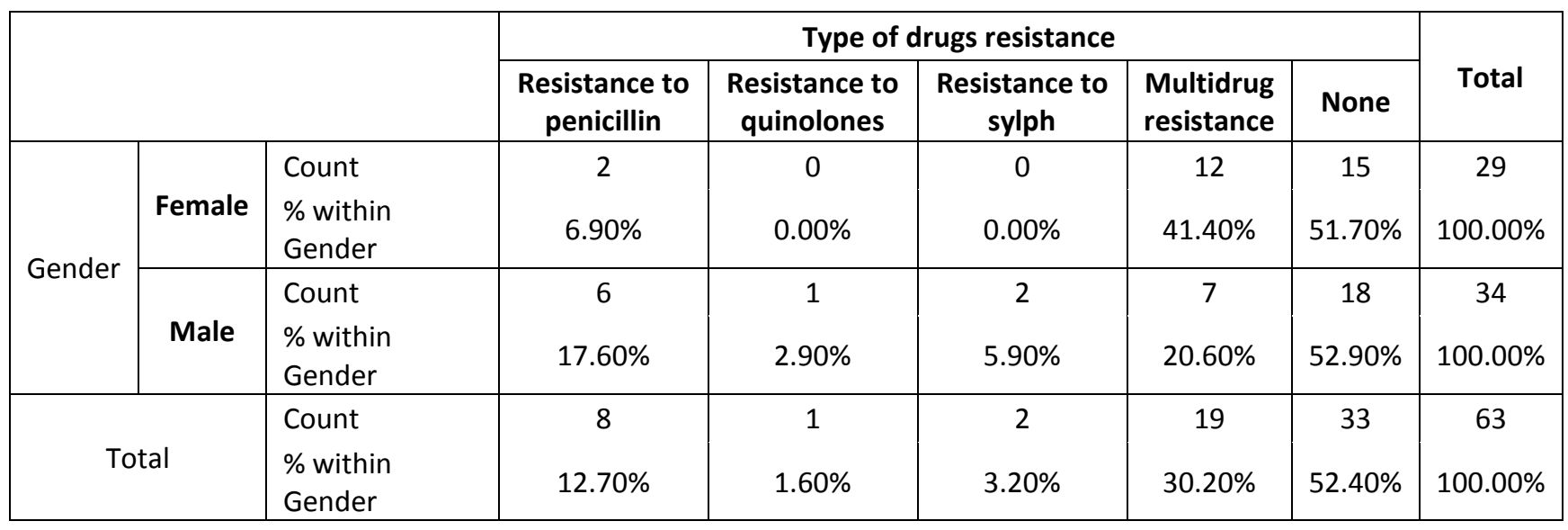

Table 6: Relationship between congenital abnormalities and drug resistance

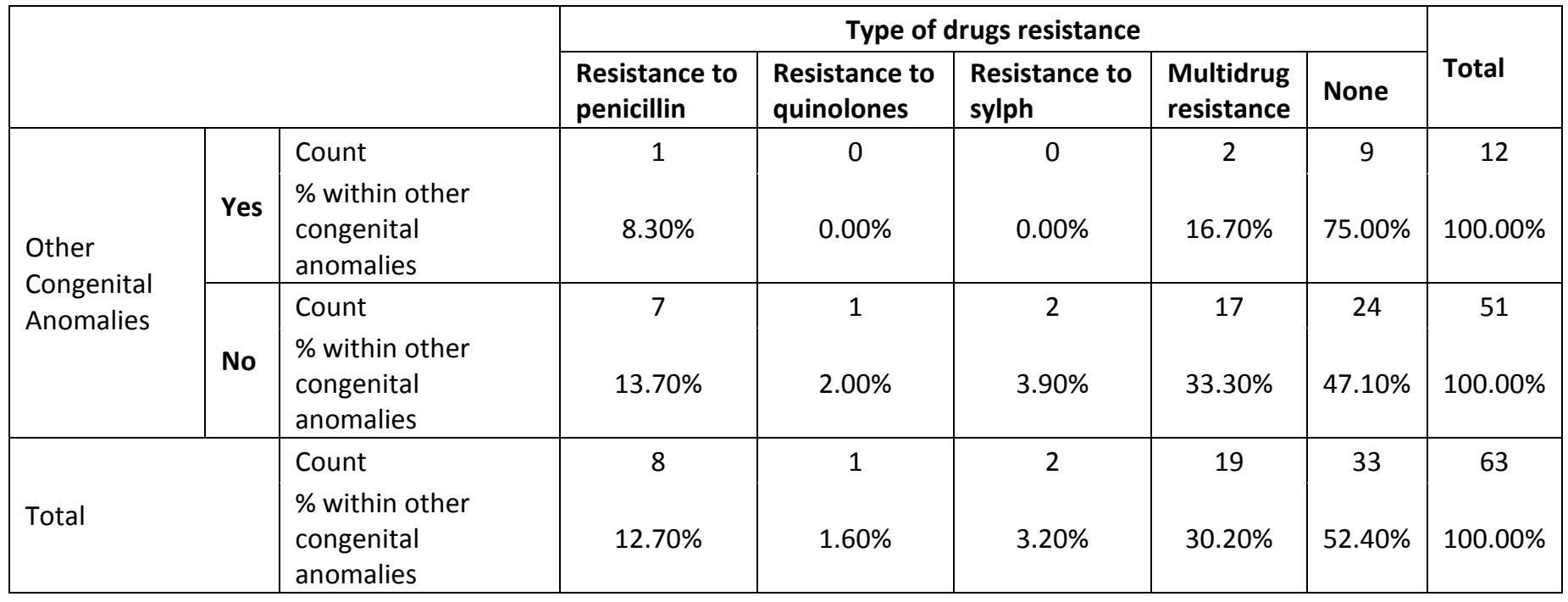

Table 7: Relationship between frequency of UTI and drug resistance

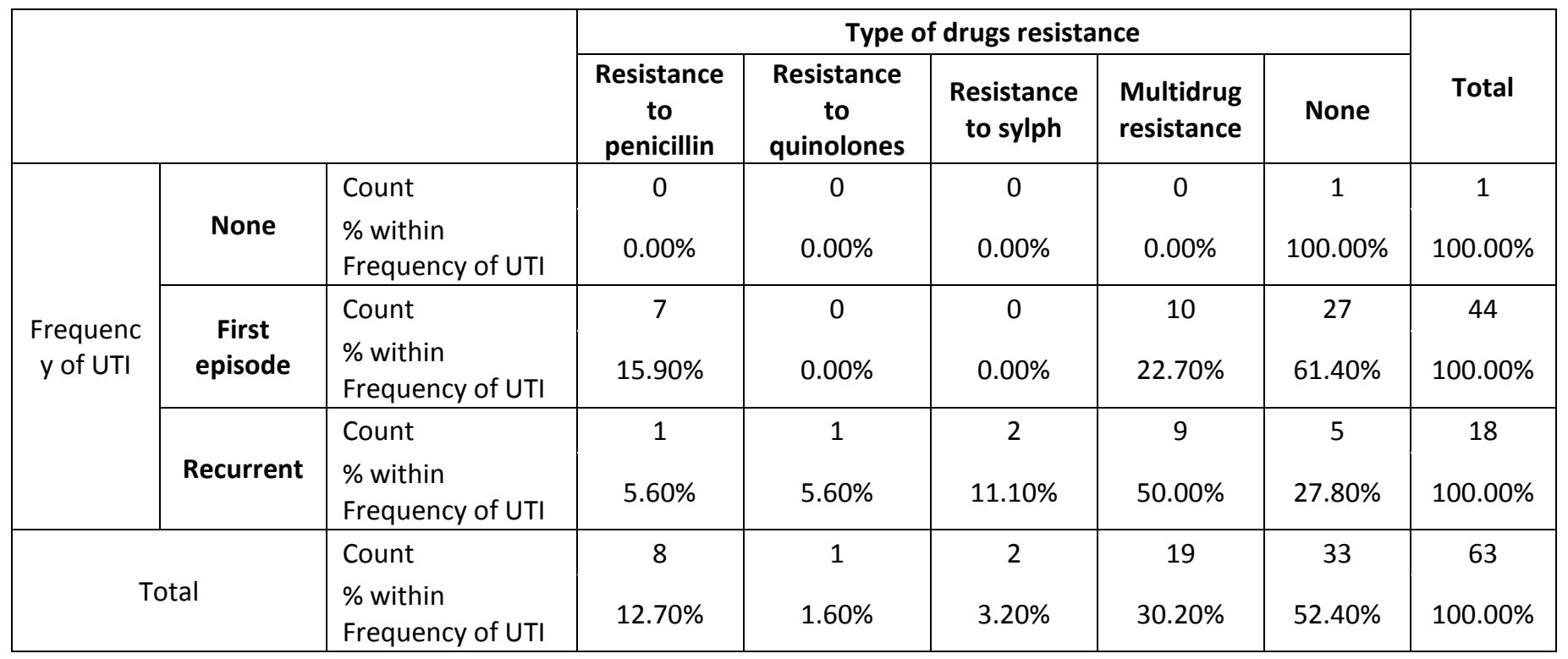


Table 8: Relationship between atypical features of UTI and drug resistance

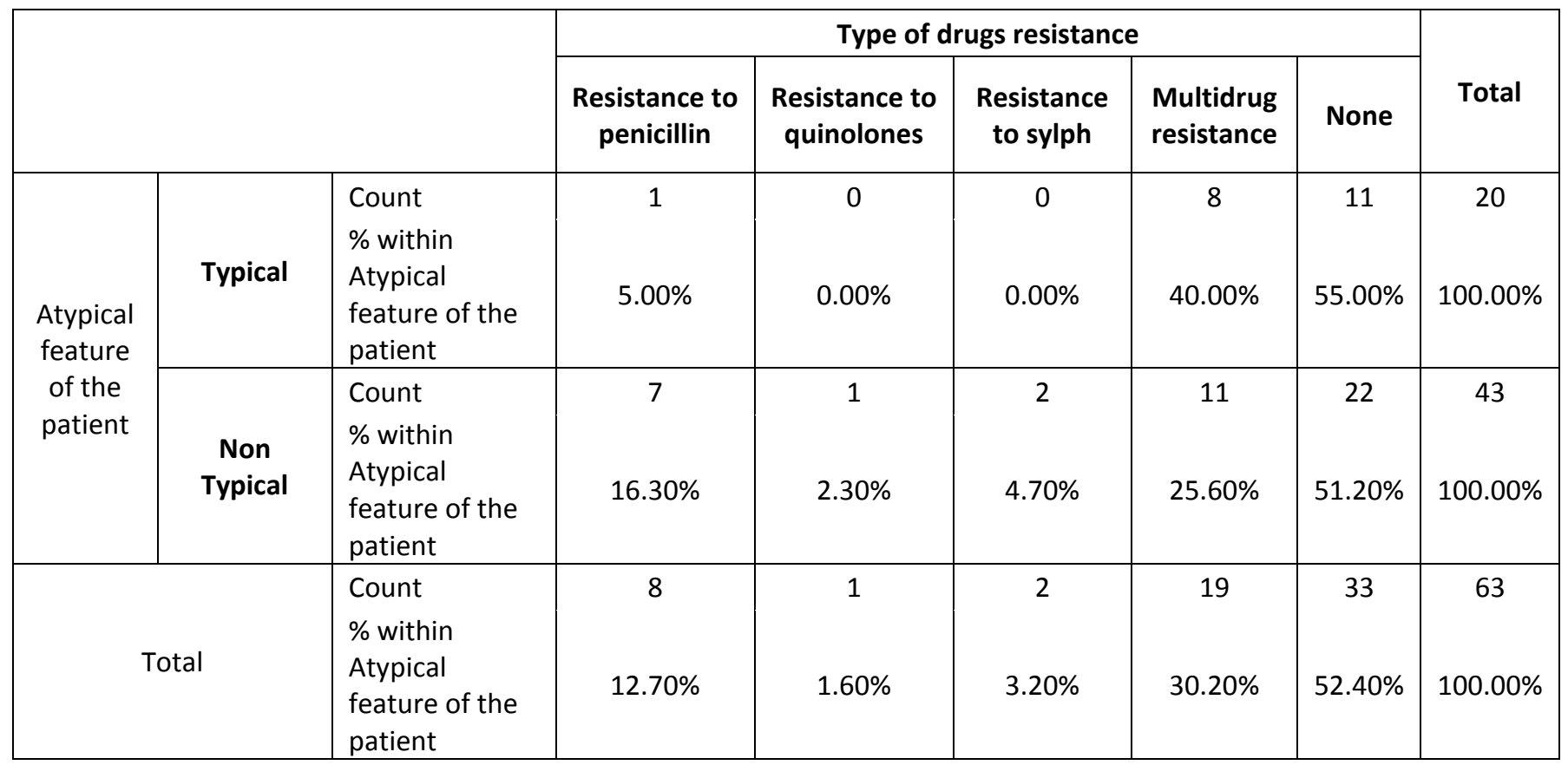

Table 9: Relationship between hydronephrosis and drug resistance

\begin{tabular}{|c|c|c|c|c|c|c|c|c|}
\hline & \multicolumn{5}{|c|}{ Type of drugs resistance } & \multirow[b]{2}{*}{ Total } \\
\hline & & & $\begin{array}{c}\text { Resistance to } \\
\text { penicillin }\end{array}$ & $\begin{array}{l}\text { Resistance to } \\
\text { quinolones }\end{array}$ & $\begin{array}{l}\text { Resistance } \\
\text { to sylph }\end{array}$ & $\begin{array}{l}\text { Multidrug } \\
\text { resistance }\end{array}$ & None & \\
\hline \multirow{3}{*}{ Hydronephrosis } & Yes & $\begin{array}{l}\text { Count } \\
\text { \% within US } \\
\text { hydronephrosis }\end{array}$ & $\begin{array}{c}1 \\
6.70 \%\end{array}$ & $\begin{array}{c}1 \\
6.70 \%\end{array}$ & $\begin{array}{c}0 \\
0.00 \%\end{array}$ & $\begin{array}{c}6 \\
40.00 \%\end{array}$ & $\begin{array}{c}7 \\
46.70 \%\end{array}$ & $\begin{array}{c}15 \\
100.00 \%\end{array}$ \\
\hline & No & $\begin{array}{l}\text { Count } \\
\text { \% within US } \\
\text { hydronephrosis }\end{array}$ & $\begin{array}{c}6 \\
15.40 \%\end{array}$ & $\begin{array}{c}0 \\
0.00 \%\end{array}$ & $\begin{array}{c}2 \\
5.10 \%\end{array}$ & $\begin{array}{c}10 \\
25.60 \%\end{array}$ & $\begin{array}{c}21 \\
53.80 \%\end{array}$ & $\begin{array}{c}39 \\
100.00 \%\end{array}$ \\
\hline & None & $\begin{array}{l}\text { Count } \\
\text { \% within US } \\
\text { hydronephrosis }\end{array}$ & $\begin{array}{c}1 \\
11.10 \%\end{array}$ & $\begin{array}{c}0 \\
0.00 \%\end{array}$ & $\begin{array}{c}0 \\
0.00 \%\end{array}$ & $\begin{array}{c}3 \\
33.30 \%\end{array}$ & $\begin{array}{c}5 \\
55.60 \%\end{array}$ & $\begin{array}{c}9 \\
100.00 \%\end{array}$ \\
\hline \multicolumn{2}{|l|}{ Total } & $\begin{array}{l}\text { Count } \\
\text { \% within US } \\
\text { hydronephrosis }\end{array}$ & $\begin{array}{c}8 \\
12.70 \%\end{array}$ & $\begin{array}{c}1 \\
1.60 \%\end{array}$ & $\begin{array}{c}2 \\
3.20 \%\end{array}$ & $\begin{array}{c}19 \\
30.20 \%\end{array}$ & $\begin{array}{c}33 \\
52.40 \%\end{array}$ & $\begin{array}{c}63 \\
100.00 \%\end{array}$ \\
\hline
\end{tabular}


Table 10: Relationship between the degree of reflux and drug resistance

\begin{tabular}{|c|c|c|c|c|c|c|c|c|}
\hline & \multicolumn{5}{|c|}{ Type of drugs resistance } & \multirow[b]{2}{*}{ Total } \\
\hline & & & $\begin{array}{l}\text { Resistance } \\
\text { to penicillin }\end{array}$ & $\begin{array}{c}\text { Resistance to } \\
\text { quinolones }\end{array}$ & $\begin{array}{c}\text { Resistance } \\
\text { to sylph }\end{array}$ & $\begin{array}{l}\text { Multidrug } \\
\text { resistance }\end{array}$ & None & \\
\hline \multirow{4}{*}{$\begin{array}{l}\text { The } \\
\text { degree of } \\
\text { reflux }\end{array}$} & Grade 1 & $\begin{array}{l}\text { Count } \\
\% \text { within The } \\
\text { degree of } \\
\text { reflux }\end{array}$ & $\begin{array}{c}0 \\
0.00 \%\end{array}$ & $\begin{array}{c}0 \\
0.00 \%\end{array}$ & $\begin{array}{c}0 \\
0.00 \%\end{array}$ & $\begin{array}{c}2 \\
100.00 \%\end{array}$ & $\begin{array}{c}0 \\
0.00 \%\end{array}$ & $\begin{array}{c}2 \\
100.00 \%\end{array}$ \\
\hline & Grade 3 & $\begin{array}{l}\text { Count } \\
\% \text { within The } \\
\text { degree of } \\
\text { reflux }\end{array}$ & $\begin{array}{c}0 \\
0.00 \%\end{array}$ & $\begin{array}{c}0 \\
0.00 \%\end{array}$ & $\begin{array}{c}0 \\
0.00 \%\end{array}$ & $\begin{array}{c}0 \\
0.00 \%\end{array}$ & $\begin{array}{c}1 \\
100.00 \%\end{array}$ & $\begin{array}{c}1 \\
100.00 \%\end{array}$ \\
\hline & Grade 4 & $\begin{array}{l}\text { Count } \\
\% \text { within The } \\
\text { degree of } \\
\text { reflux }\end{array}$ & $\begin{array}{c}0 \\
0.00 \%\end{array}$ & $\begin{array}{c}0 \\
0.00 \%\end{array}$ & $\begin{array}{c}0 \\
0.00 \%\end{array}$ & $\begin{array}{c}0 \\
0.00 \%\end{array}$ & $\begin{array}{c}1 \\
100.00 \%\end{array}$ & $\begin{array}{c}1 \\
100.00 \%\end{array}$ \\
\hline & None & $\begin{array}{l}\text { Count } \\
\% \text { within The } \\
\text { degree of } \\
\text { reflux }\end{array}$ & $\begin{array}{c}8 \\
13.60 \%\end{array}$ & $\begin{array}{c}1 \\
1.70 \%\end{array}$ & $\begin{array}{c}2 \\
3.40 \%\end{array}$ & $\begin{array}{c}17 \\
28.80 \%\end{array}$ & $\begin{array}{c}31 \\
52.50 \%\end{array}$ & $\begin{array}{c}59 \\
100.00 \%\end{array}$ \\
\hline \multicolumn{2}{|l|}{ Total } & $\begin{array}{l}\text { Count } \\
\% \text { within The } \\
\text { degree of } \\
\text { reflux }\end{array}$ & $\begin{array}{c}8 \\
12.70 \%\end{array}$ & $\begin{array}{c}1 \\
1.60 \%\end{array}$ & $\begin{array}{c}2 \\
3.20 \%\end{array}$ & $\begin{array}{c}19 \\
30.20 \%\end{array}$ & $\begin{array}{c}33 \\
52.40 \%\end{array}$ & $\begin{array}{c}63 \\
100.00 \%\end{array}$ \\
\hline
\end{tabular}

